\author{
Олена Леонідівна Львова, \\ стариий науковий співробітник відділу \\ теорії держави і права Інституту держави і права \\ ім. В.М. Корецького НАН Украӥни, \\ кандидат юридичних наук
}

\title{
КРИТЕРІЇ МОРАЛЬНОСТІ І ПРИРОДНОСТІ У СУЧАСНОМУ ПРАВОТВОРЕННІ
}

Постановка проблеми. Носієм духовних, культурних і моральних цінностей життя людини, суспільства та держави здатне стати законодавство, яке будуватиметься на відповідних ідеологічних, природно-правових засадах. Зробити це на найвищому законодавчому рівні покликаний Основний Закон держави, закріпивши фундаментальні, непохитні ідеали та цінності народу, які формувалися протягом усієї історії. Їх серцевиною повинна стати людина, ії матеріальне благополуччя, розвиток духовного потенціалу, творчих здібностей і фізичної досконалості [8, с. 449].

Адже суспільство, у якому досягнуто консенсусу відносно того, що є моральним, що вважати цінністю, а що ні, може розглядатися як стабільна система, оскільки ліквідується головне джерело протиріч, які породжують нестабільність, катаклізми, потрясіння [29, с. 9].

Зазначене викриває актуальність та подальшу потребу у дослідженні питання праворозуміння, зокрема, у контексті розмежування категорій «право» і «закон», відповідно через природне та позитивне праворозуміння, з'ясування змісту правового закону та його критеріїв, які мають враховуватися у правотворчій діяльності. Вказане сприятиме не лише якості самого нормативно-правового акта, а й ефективності і дієвості в процесі його реалізації та застосування.

Аналіз останніх досліджень та публікацій. У науковому дискурсі дана проблема не $є$ новою. Розкриваючи ідею природного права, правових законів та моральності, а також інші аспекти згаданих питань висвітлювалися у дослідженнях О. Богінича, М. Козюбри, В. Костицького, О. Костенка, О. Макаренко, Н. Оніщенко, П. Рабіновича, В. Сіренка та інших вчених правознавців. Поза тим, досить актуальною та недослідженою залишається проблема меж між моральними та аморальними явищами, між свободою і вседозволеністю, що мало б стати законодавчою гарантією для захисту людської гідності та національної ідентичності. Зокрема, потребують поглибленого аналізу критерії, які мають ідентифікувати закон як правовий в процесі правотворчої діяльності.

Мета статті. Яким сьогодні має бути закон і які основні критерії визначатимуть його як правовий? Яку роль відіграють критерії моральності і природності у правотворчості й загальній консолідації суспільства? Ставимо на меті надати відповідь на ці питання.

Основні результати дослідження. Українські правознавці визначають, що сутність правотворення засновується: по-перше, на концепції спільності та відмінності права і закону, що передбачає існування і поза формою свого інституційного виразу (тобто поза законодавством) у вигляді рівної і справедливої міри свободи, яка відображена у правових принципах, суб'єктивних правах, конкретних правовідносинах і т. i.; i, по-друге, на теоріях правової держави і громадянського суспільства. Причому громадянське суспільство безпосередньо утворює право в формі типових конкретних правовідносин, що зумовлені соціальними чинниками, емпіричною правосвідомістю населення. А держава формулює це «право суспільного життя» у формалізованих, загальнообов'язкових правилах поведінки, зовнішньо відображених у законодавстві - системі нормативно-правових документів [2, с. 159].

Увесь процес правотворчості має відбуватися з урахуванням основоположних соціальних цінностей, з формуванням позитивних ціннісних установок, зорієнтованих на загальнолюдське, абсолютне й вічне. Тобто за відображення ціннісних установок у законодавстві відповідальною $є$ особа, яка безпосередньо займається правотворчою діяльністю [20, с. 42].

Недосконалість та навіть криза діяльності державних органів, правотворчих зокрема, сьогодні характеризується передусім корупційною складовою, в основі якої лежать моральні критерії. I це, як справедливо підкреслює Л. Макаренко, пов’язане із професійною деформацією особистості 
державного службовця, подолання чого, як зазначається, є однією з найголовніших суспільних цінностей на шляху до духовного відродження України у часи кризи [14, с. 212-213].

Історія також доводить, що кризи у державно-правових процесах породжуються, передусім, кризами моралі, які беруть свій початок з людини чи групи людей, на яких лежить тягар відповідальності за свій народ. Зокрема, історія Реформації 1517 р. своїм переворотом засвідчила критичний стан тогочасної держави, церкви та людини і стала дороговказом до цивілізаційного розвитку. Очевидно, що зміна ідеологічних парадигм змінила свого часу не лише церкву, людину, а й усі сфери суспільства - культуру, освіту, економіку, право, державну владу тощо. Основою цих змін стало повернення до витоків віри та правди, яка була викладена у Біблії, до цінностей і принципів, які реконструювалися з неї та шляхом наполегливої боротьби та праці зайняли своє місце у законодавчому масиві.

Вказане спонукає до тези, що правотворча діяльність держави, її органів та посадових осіб має будуватися, виходячи із принципу відповідальності перед Богом, перед власною совістю і перед майбутніми поколіннями, як це викладено у Преамбулі Конституції України. Така відповідальність починається з відповідальності окремої посадової особи, тобто людини, яка є істотою, що належить одночасно декільком світам: божественному, надприродному, космічно-природному, соціальному, культурному й правовому. I, як наголошує Н. Оніщенко, складність людського існування полягає у тому, що воно відбувається одночасно у декількох вимірах: у природному, в соціумному, культурному, політичному, правовому. I жодна із цих сфер не може бути безболісно відірвана від людини. У соціокультурному середовищі людина має знаходити засоби подолання тих суперечностей, що виникають між природним і духовним, буденним і культурним [19, с. 72-73].

Зазначене покладає суворі етичні вимоги до осіб, які несуть тягар здійснення державної влади, що, зокрема, відображено: у ст. 4 Закону України «Про державну службу в Україні» [4], де визначаються принципи державної служби (верховенство права, законність, доброчесність, рівність тощо); у ст. 22 Закону України «Про запобігання корупції» [5], яка містить обмеження щодо використання службових повноважень чи свого становища та щодо одержання подарунків i т. i., a розділ V даного Закону містить ряд етичних норм щодо поведінки і способу життя державних службовців; у п. 9 «Загальних правил етичної поведінки державних службовців та посадових осіб місцевого самоврядування» [3] визначається, що в процесі своєї діяльності вони «мають шанувати народні звичаї і національні традиції» тощо.

Згадані положення лежать у площині моралі та відповідних цінностей, які, зокрема, відображають одну із можливих сучасних парадигм розуміння права - ціннісно-нормативну. 3 огляду на це Ю. Оборотов визначає право як історично сформовану, морально обгрунтовану та релігійно вивірену, легалізовану ціннісно-нормативну систему, яка розрахована на всезагальне визнання (легітимацію) і відповідну поведінку людей, організацій, соціальних спільнот, яка використовує процедури, формалізовані рішення і державний примус для попередження і вирішення конфліктів, збереження соціальної цілісності [18, с. 5].

Із даного визначення випливає, що сфера моралі й цінностей не належить суто суб'єктам правотворчості (чи законотворчості), передусім вона народжується із природи суспільних відносин і для її нормативного прояву має бути визнана народом. Це також вказує на фактичне розрізнення понять права і закону. Тому що їх ототожнення призводить до хибного висновку про те, що у часи, коли не існувало держави і закону, не було й права, i таке припущення призводить до абсурду [9, с. 52]. Тобто право є об'єктивною реальністю, що існує завжди, воно визначається загальносуспільним усвідомленням морального, справедливого, природного та істинного, що приносить благо як окремому індивіду, так і суспільству.

Тому, на наше переконання, суб'єкт правотворчості своєю головною метою має таке подвійне завдання: 1) співвідносити свою особистість і внутрішні моральні якості з соціокультурним, моральним контекстом суспільного життя конкретного народу; 2) здійснювати спостереження та моніторинг права, що де-факто, природно або в силу традиції чи звичаїв існує у суспільних відносинах, і формалізувати його у вигляді конкретних правових норм з метою консолідації суспільства й захисту природних прав людини.

Водночас маркерами такої відповідності мають стати обгрунтовані критерії, головними серед яких ми вважаємо критерії моральності і природності.

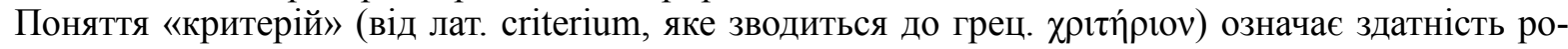
зрізнення; засіб судження, мірило, пов’язане з грец. $\chi \rho \imath \omega-$ розділяю, розрізняю) - мірило, вимоги, 
випробування для визначення або оцінки людини, предмета, явища; ознака, взята за основу класифікації; підстава для оцінки, визначення або класифікації чогось; мірило [13, с. 36].

Щодо моральності і природності, то вони водночас $є$ критеріями істини, яка не заперечується, оскільки існує незалежно від свідомості і діяльності людини. Словник української мови критерій істини тлумачить як мірило істинності, вірогідності людських знань, їх відповідності об'єктивній дійсності [25, с. 349]. Поняття дійсності, у свою чергу, зводиться до розуміння її як об'єктивної реальності в усій ії конкретності, сукупності природних та суспільно-історичних явищ [26, с. 368].

Переходячи власне у юридичну площину, можна стверджувати, що право, яке існує об'єктивно, не залежно від людини, $є$ природним правом, тобто істинним. Таке право направлене на суспільне благо i, формуючись під впливом історичних, морально-етичних та інших факторів, стає невід'ємною частиною суспільного життя, оскільки сприйняте як суспільством, так і окремим індивідом як щось природне і беззаперечне.

Відповідно до концепції природного права моральне благо визначає таку морально-правову норму, дотримуючись якої, людина може досягти бажаного блага. Щодо критерію відмежування правового від неправового, то природно-правова традиція виходить із розуміння, що правовим $\epsilon$ все те, що відповідає ідеї справедливості та істинності [12, с. 36].

В. Сіренко, вивчаючи питання демократичної, правової, соціальної держави, вказує на суспільство справедливості, в якому мріють жити люди, де закон визначає цінності життя, рівність і суспільне благо для усіх. I без сумніву, що ідеї про необхідність панування закону над владою виникли як реакція на свавілля, деспотію, тиранію, як протиотрута від зловживання владою [24, c. 101]. Якщо згадати правотворчість радянської доби, то вона відрізнялася політичним характером законів, які були не засобом гарантування та захисту природних прав людини, а інструментом ствердження інтересів правлячої верхівки.

В. Селіванов наголошує з цього приводу, що в Україні має відбутися послідовна заміна «успадкованої» від колишнього СРСР радянської правової дійсності, правової системи. При цьому вчений наголошує, що всебічному уявленню про природу права і закону та їх взаємозв'язок сьогодні заважають залишки однобічного підходу до розуміння права, а саме - розуміння його лише як юридичного, позитивного права, як результату діяльності держави, іiї органів, зведення його сутності в найкращому разі до закону [23, с. 7].

Ця теза вказує на нетотожність права і закону, хоча й не заперечується їх об'єктивний взаємозв'язок. Так, М. Тесленко підкреслює, що право $є$ безперервним процесом, створюваним суспільством, і закони виступають лише його тимчасовим відображенням, вони повинні еволюціонувати разом із змінами соціального середовища. Право повинно орієнтуватися на розвиток і прогрес суспільства, від цього залежить його авторитет. Тому різноманітні фундаментальні цінності, що формуються у процесі розвитку суспільства, потрібно трансформувати у національну систему. Саме правові позиції Конституційного Суду Україні спроможні розкривати особливості права як «живого організму» і виявляти приховані загальні принципи права, які мають не менше значення, ніж сама Конституція України, і служать ідейною основою для об'єктивного права [28, с. 41-42].

Зокрема, істина про нетотожність права і закону, а також ідея пріоритету права над законом знайшла відображення у конституційному принципі верховенства права, який згідно з рішенням Конституційного Суду України від 2 листопада 2004 р., тлумачиться як «панування права в суспільстві», що «...вимагає від держави його втілення у правотворчу та правозахисну діяльність, зокрема, у закони, які за своїм змістом мають бути проникнуті передусім ідеями соціальної справедливості, свободи, рівності тощо. Одним із проявів верховенства права $є$ те, що право не обмежується лише законодавством як однією з його форм, а й включає й інші соціальні регулятори, зокрема, норми моралі, традиції, звичаї тощо, які легітимовані суспільством і зумовлені історично досягнутим культурним рівнем суспільства» [22].

Тобто мова йде, як влучно зазначає В. Сіренко, про піднесення права над державою, про таке його значення, коли право заперечується як придаток державної влади. Звідси вчений закономірно підіймає питання про співвідношення права і закону і констатує факт невирішеної проблеми величезної соціальної значущості щодо критеріїв правового і неправового закону. Адже, якби вдалося сформулювати чіткі правові критерії розмежування правового і неправового закону, то це б суттєво змінило діяльність усього державного механізму, надало б суспільству досконалий інструмент контролю за діяльністю держави, встановило б основоположний принцип життєдіяльності будь-якої 
держави - принцип соціальної справедливості [24, с. 104-105]. Вирішення даного завдання потребує наукової єдності щодо праворозуміння, особливо стосовно понять права як природного явища і закону як результату правотворчої діяльності компетентного державного владного органу.

Аналіз філософсько-правової думки надав змогу українським вченим виділити два підходи до розуміння природного права і його співвідношення з позитивним, а саме: 1) як сукупності апріорних моральних вимог, пропонованих до позитивного права, як критичної інстанції, що дає моральну оцінку позитивного права 3 погляду його справедливості або несправедливості (Платон, І. Кант); 2) як необхідної і незмінної основи чинного законодавства, що не існує поза ним; тут природно-правові принципи визначалися всередині чинного права, що мислилося як ідея права, яка реалізується в історії (Арістотель, Г. Гегель) [15, с. 892].

Зокрема, у 2010 р. С. Рабінович представив світу свою фундаментальну працю «Природноправові підходи в юридичному регулюванні» [21], де широко і всебічно підійшов до вивчення нових сучасних концепцій у праві. Вчений глибоко розглянув природно-правову парадигму в ії зв'язку з юридичною практикою, де предметом вивчення стали засновані на природно-правовій парадигмі різноманітні світоглядно-методологічні та юридико-прикладні підходи, способи вироблення правотлумачних та правозастосовних рішень. 3 огляду на те, що загальна лібералізація державної юридичної політики породжує потребу в теоретичному обгрунтуванні та юридичному забезпеченні певних ідеалів, видатний вчений звертається до тих концептуальних підходів та учень, на основі яких у західноєвропейській традиції права вироблені й розробляються такі правові ідеали, як основоположні права людини, принципи верховенства права та правової держави $[21$, с. 5].

Отже, природність конституційно закріплених прав сьогодні не підлягає сумніву і $є$ тим критерієм, на який необхідно орієнтуватися в процесі правотворчої діяльності задля уникнення соціальних протиріч. 3 огляду на те, що у сучасних умовах стрімкої лібералізації правового життя чимало проектів нормативно-правових актів не мають свого наукового обгрунтування і, відповідно, залишаються відірваними від об'єктивної істини і природного стану речей.

На сьогодні проблема моральних імперативів в системі прав людини вельми гостро постає 3 огляду на певні новели вітчизняного законодавства, що вступають у протиріччя із природою речей, з віковими традиціями українського народу i, власне, з конституційним принципом верховенства права. Особливо це стосується свободи й гідності людини, а також сфери сім'ї та суспільної моралі, які знецінюються та руйнуються в Україні під прикриттям невинних, так би мовити, понять, таких, як толерантність, рівність, свобода, дискримінація та ін.

О. Костенко, розвиваючи аналогічну думку, вказує на єдине істинне джерело законів існування, називаючи його Мати-Природа - це те, що породжує усе суще і дає йому Закони для існування, утворюючи таким чином Світопорядок, а також ту його сферу, яка називається Соціальним Порядком. У даному разі «протиприродність» означатиме, що явище у своєму існуванні порушує ті закони, які Мати-Природа дала саме для нього, а не закони, за якими мають існувати інші явища $[10$, с. 6-7]. Протиприродність певних явищ суспільного життя, що претендує на статус природності на рівні законотворчості, породжує проблему аморальності і, відповідно, конфлікту між учасниками правовідносин.

С. Сунєгін справедливо зауважує, що в умовах глобального поширення ліберальної ідеології суспільного життя, тенденція до тотальної автономізації змісту всіх соціальних регуляторів, що виявляється у масовому поширенні серед громадян переконання, згідно з яким право, мораль і релігія повинні підпорядковуватися негайним особистим інтересам та бажанням індивідів.

Якщо вчасно це не усвідомити, катастрофічні наслідки ліберальної глобалізації та породженої нею руйнації нормативності соціального порядку внаслідок порушення цілісності об'єктивносуб'єктивних засад розвитку та функціонування людини і суспільства, можуть поставити під питання навіть саме людське життя на планеті Земля, на необхідності збереження якого постійно акцентують увагу апологети глобального ліберально-демократичного порядку [27, с. 161].

3 огляду на те, що джерелом виникнення світських норм залишаються звичаї, традиції, мораль, то задля запобігання соціального хаосу професор В. Костицький пропонує просте вирішення проблеми: наші права мають межу, яка знаходиться там, де починаються права інших осіб. Тільки моральний зміст права може бути основою правопорядку. Аморальний закон приречений на суспільний негативізм, громадський осуд; він не виконує однієї з основних функцій права - не формує правового порядку [11, с. 7]. 
На законодавчому рівні питання моралі регулюється законом України «Про захист суспільної моралі», що встановлює правові основи захисту суспільства від розповсюдження продукції, що негативно впливає на суспільну мораль. У ст. 1 даного Закону суспільна мораль визначається як система етичних норм, правил поведінки, що склалися у суспільстві на основі традиційних духовних і культурних цінностей, уявлень про добро, честь, гідність, громадський обов'язок, совість, справедливість [6].

Утім, у державі відбувається чимало деструктивних явищ, що йдуть всупереч уявленням про мораль і які спричинені саме спонуканнями до толерантності, зміст і межі якої законодавчо не визначені. Як приклад, слід згадати так звані марші «рівності» ЛГБТІ, мітинг секс-працівниць 3 вимогою легалізувати проституцію як вид підприємницької діяльності, антидискримінаційну експертизу шкільних підручників, що суперечить культурі й цінностям українського суспільства тощо. Особливо бажаємо зупинитися на останньому, що де-факто висвітлить проблему неврахування у правотворчій діяльності органами державної влади критеріїв природності та моральності.

Так, ми проаналізували текст проекту таких документів Міністерства освіти і науки України, як Стратегія упровадження гендерної рівності та недискримінації у сфері освіти «Освіта: гендерний вимір-2021» та чинний наказ Міністерства освіти і науки України № 1183 від 31 жовтня 2018 p. «Про затвердження інструктивно-методичних матеріалів для проведення експертами експертиз електронних версій проектів підручників» [16].

Стосовно чинного наказу МОН, то його положення в частині антидискримінаційної експертизи знецінюють авторитет права та законодавства. Зокрема, на стор. 14 наказу визначено таке: «Обов'язковим $є$ використання авторами/-ками термінології, яка відповідає не лише законодавству, але й вимогам, що висуваються групами людей, які об'єднані певними ознаками». Слід звернути увагу на формулювання «групи людей, які об'єднані певними ознаками»: що це за групи, які саме ознаки їм притаманні, та чи є їх вимоги законними? 3 огляду на вказане слід констатувати зневагу до законів та принципів, на яких має будуватися уся правотворча діяльність державних органів, зокрема, принцип верховенства права та науковості. «Вимоги, що висуваються групами людей», як свідчить наукова юридична доктрина і практика, не є джерелом права, а отже, вони не можуть покладатися в основу будь-якої експертизи.

Також, звертаючись до проекту «Стратегії упровадження гендерної рівності та недискримінації у сфері освіти «Освіта: гендерний вимір-2021», що передував згаданому вище наказові МОН, навіть не поглиблюючись у ії зміст, виникають сумніви щодо правової та наукової обгрунтованості даного документа. Особливу увагу звертає на себе термін «гендерний вимір». Чому саме гендерний? Чи є офіційні статистичні дані щодо гендерної дискримінації та порушень прав дитини у даній сфері в шкільних навчальних закладах? Чому наразі підіймається саме цей, а не інший критерій? До змісту гендерної рівності та недискримінації, як засвідчили результати експертизи, яка здійснювалася приховано, вона проводилася так званими експертами без відповідного фаху і досвіду, було залучено, як антидискримінаційні, такі терміни, як боротьба зі стереотипами, толерантність, одностатеві стосунки як ще одна модель сім’ї на рівні із природною сім'єю і т. i.

Отже, на догоду даній Стратегії впроваджено й експертизу шкільних підручників, при цьому жодним чином не переконується, чому саме принцип недискримінації має стати основоположним у процесі експертної оцінки підручників та по надаваному йому експертами значенню перевершує конституційний принцип верховенства права в Україні, який визначений у ст. 8 Конституції України та ст. 6 Закону України «Про освіту». Окрім того, сучасна українська юридична наука принцип рівності не ототожнює з однаковістю і визнає існування природної нерівності, що має враховуватися в процесі правотворчості. Ігнорування зазначеного в освітньому процесі породжує штучно насаджувану рівність чоловіків і жінок (хлопчиків та дівчаток), яка нівелює природні властивості статі і намагається досягти їх цілковитого зрівняння. Дана стратегія стосовно природних моделей поведінки дівчат/хлопців та жінок/чоловіків насаджає клішування поведінкових проявів терміном «гендерний стереотип», чим розмиває природний характер прав людини. Тобто на рівні правотворчої діяльності окремих державних органів відбувається нав'язування антинаукових і аморальних постулатів гендерної ідеології в освітньому процесі.

У даному разі порушується право батьків на виховання власних дітей згідно з їх світоглядними переконаннями та обов'язок батьків впливати на освітній процес, що закріплено в низці міжнародних договорів, ратифікованих Україною, зокрема п. 4 ст. 18 Міжнародного пакту про громадянські 
і політичні права 1966 р., п. 3 ст. 13 Міжнародного пакту про економічні, соціальні і культурні права 1966 р., п. 2 ст. 3, 5, п. 2 ст. 14 та п. 1(с) ст. 29 Конвенції ООН про права дитини 1989 р.

Зазначене також свідчить про те, що в даному разі ні критерій природності, ні критерій моральності не стали стандартом і мірилом правотворчої діяльності МОН і це не просто не сприяло консолідації суспільства, а спричинило конфлікт інтересів батьків, громадських просімейних організацій та наукової спільноти [1;17].

Виходячи з положень ст. 6 Закону України «Про освіту» [7], засадами державної політики у сфері освіти та принципами освітньої діяльності є: верховенство права; нерозривний зв'язок із світовою та національною історією, культурою, національними традиціями; виховання патріотизму, поваги до культурних цінностей Українського народу, його історико-культурного надбання і традицій і т. i.

3 огляду на вказане викликає сумнів існування правових, обгрунтованих підстав щодо нагальної потреби такого виду експертизи.

Отже, така антидискримінаційна експертиза навчальних підручників вочевидь $є$ як науково не обгрунтованою, i, виходячи із законодавчо визначених завдань та принципів освіти в Україні, має бути скасована запроваджувана Стратегія упровадження гендерної рівності та недискримінації у сфері освіти «Освіта: гендерний вимір-2021».

У контексті зазначеного доцільно процитувати О. Костенко, який говорить про ідею протиприродності як кореня соціальних паталогій: «3 принципу соціального натуралізму, - пише вчений, випливає, що універсальним критерієм для діагностування соціальних патологій є критерій протиприродності: усе те, що $є$ протиприродним, $є$ соціальною патологією, тобто $є$ злом» $[10$, с. 28, 137].

Висновки. Отже, право $є$ об'єктивною реальністю, що визначається загальносуспільним усвідомленням морального, справедливого, природного та істинного, що приносить благо як окремому індивіду, так і суспільству в цілому. Законодавство, як форма відображення права, має відповідати критеріям природного і морального, що притаманні конкретному суспільству, які водночас $\epsilon$ критеріями істини, яка існує незалежно від свідомості і діяльності людини. Тобто право, формуючись під впливом історичних, морально-етичних та інших факторів, стає невід'ємною частиною суспільного життя, воно існує об'єктивно, тобто є природним правом, є істинним.

3 огляду на це суб'єкт правотворчості своєю головною метою має таке подвійне завдання: 1) співвідносити свою особистість і внутрішні моральні якості з соціокультурним, моральним контекстом суспільного життя конкретного народу; 2) здійснювати спостереження та моніторинг права, що де-факто, природно або в силу традиції чи звичаїв існує у суспільних відносинах, і формалізувати його у вигляді конкретних правових норм 3 метою консолідації суспільства й захисту природних прав людини.

\section{Список використаних джерел}

1. Громадські організації підтримують просімейну й антигендерну позицію секретаря РНБО // Цензор.Нет. 29.12.2018. URL: https://m.censor.net.ua/ua/news/3104609/gromadski_organizatsiyi_pidtrymuyut_prosimeyinu_ yi_antygendernu_pozytsiyu_sekretarya_rnbo?fbclid=IwAR1 yunGF75̄6hs6d-gQrTEz214ZPyUN_CijhRHr7SYTaCrvtmv1-V7cK8y0

2. Загальна теорія держави і права : навч. посіб. / [за ред. В. В. Копєйчикова]. К. : Юрінком Інтер, 2000. 320 с.

3. Загальні правила етичної поведінки державних службовців та посадових осіб місцевого самоврядування: Затверджено наказом Національного агентства України з питань державної служби від 05.08.2016. № 158 // Oфіційний веб-портал Верховної Ради України. URL: http:zakon3.rada.gov.ua/laws/show/z1203-16/paran13\#n13.

4. Закон України «Про державну службу в Україні» № 889-VIII від 10.12.2015 р. // Офіційний веб-портал Верховної Ради України «Законотворчість». URL: http://zakon2.rada.gov.ua/laws/show/889-19.

5. Закон України «Про запобігання корупції» від 14 жовтня 2014 року № 1700-VII // URL: Офіційний веб-портал Верховної Ради України. URL: http:zakon3.rada.gov.ua/laws/show/1700-18/page.

6. Закон України «Про захист суспільної моралі» від 20 листопада 2003 р. № 1296-IV // Офіційний веб-портал Верховної Ради України «Законотворчість». URL: http://zakon.rada.gov.ua/laws/show/1296-15

7. Закон України «Про освіту» № 2145-VIII від 05.09.2017 р. Офіційний веб-портал Верховної Ради України «Законотворчість». URL: https://zakon.rada.gov.ua/laws/show/2145-19

8. Козловець M. A. Феномен національної ідентичності: виклики глобалізації : монографія. Житомир: Вид-во ЖДУ ім. І. Франка, 2009. С. 449.

9. Коржанський М. Й. Право і закон // Науковий вісник Юридичної академії Міністерства внутрішніх справ : Збірник наукових праць. 2003. № 3 (12). С. 52-52.

10. Костенко О. М. Культура і закон - у протидії злу: монографія. К. : Атіка, 2008. 352 с. 
11. Костицький В. В. Норма права як соціальний феномен: теолого-соціологічне праворозуміння // Соціологія права: науково-практичний журнал. 2015. №№ 3-4 (14-15). С. 3-10.

12. Кравець В. М. Природне право як ідея та ідеал позитивного права // Філософські та методологічні проблеми права. Вип. 1. К. : 2009. С. 35-41.

13. Критерій // Наука і життя. Вип. 8. 1956. С. 36.

14. Макаренко Л. О. Корупція як визначальний фактор руйнування правової культури в Україні // Альманах права. Правова аналітика: доктринальні підходи та галузеві виміри. Вип. 9. К. : Ін-т держави і права ім. В. М. Корецького НАН України, 2018. С. 208-215.

15. Максимов С. Природне і позитивне право як елементи правової реальності // Міжнародна поліцейська енциклопедія: у 10 т. Відп. ред. Ю. І. Римаренко, Ч. Ю. Кондратьєв та ін. К. : Ін Юре, 2003. С. 891-894.

16. Наказ МОН України № 1183 від 31 жовтня 2018 р. «Про затвердження інструктивно-методичних матеріалів для проведення експертами експертиз електронних версій проектів підручників» // Офіційний сайт Міністерства освіти і науки України. URL: https://mon.gov.ua/ua/npa/pro-zatverdzhennya-instruktivno-metodichnihmaterialiv-dlya-provedennya-ekspertami-ekspertiz-elektronnih-versij-proektiv-pidruchnikiv

17. Науковиі закликають Кабмін ліквідувати посаду уповноваженого з питань гендерної політики // «Всі разом». Громадянський рух. 29.12.2018. URL: https://vsirazom.ua/poziciya/naukovci-zaklikayut-kabmin-likviduvatiposadu-upovnovazhenogo-z-pitan-genderno\%D1\%97-politiki?fbclid=IwAR1JJ3QFzMy7fWHDsFMfNHFyjfYXbS sywy9WW5131YkrI_dNG_7vu-IHahQ

18. Оборотов Ю. Н. Парадигма ценностно-нормативного понимания // Правове життя сучасної України: Тези доповідей Всеукраїнської наукової конференції / Відп. ред. проф. Ю. М. Оборотов. О. : Фенікс, 2008. С. 5-6.

19. Оніменко Н. М. Правовий світогляд: людиноцентриський вимір // Трансформація правової ідеології у контексті сучасних викликів : монографія / кол. авторів; за заг. ред. Н. М. Оніщенко. К. : ТОВ «Нілан-ЛТД», 2016. C. 63-105.

20. Плавич С. В. Теоретико-методологічні засади правотворчості : дис. ...канд. юрид. наук : 12.00.01. К., 2009. 215 с.

21. Рабінович С. П. Природно-правові підходи в юридичному регулюванні : монографія. Львів : Львів. держ. ун-т внутр. справ, 2010. 576 с.

22. Рішення Конституційного Суду України № 15-рп/2004 від 02 листопада 2004 р. по справі № 1-33/2004 за конституційним поданням Верховного Суду України щодо відповідності Конституції України (конституційності) положень статті 69 Кримінального кодексу України (справа про призначення судом більш м'якого покарання) // Офіційний веб-портал Верховної Ради України «Законотворчість». URL: http://zakon3.rada.gov.ua/laws/ show/v015p710-04.

23. Селіванов В. Нетотожність права і закону (методологічний аспект) // Право України. 2005. № 5. С. 7-11.

24. Сиренко В. Государство: демократическое, правовое, социальное (Очерки. Дискуссионные вопросы). К. : Ин-т государства и права им. В. М. Корецкого НАН Украины, 2013. 340 с.

25. Словник української мови: в 11 томах / Ред. кол. : І. К. Білодід (гол.) та ін. К. : Наукова думка, 1970-1980. T. $4.1973 .840 \mathrm{c}$.

26. Советский энциклопедический словарь / глав ред. А. М. Прохоров. Изд. 2-е. М. : Сов. энц., 1983.1600 с.

27. Сунєгін С. О. Право, мораль і релігія як соціальні регулятори: об'єктивний та суб'єктивний виміри // Правова держава. Вип. 28. К. : Ін-т держави і права ім. В. М. Корецького НАН України, 2017. С. 145-163.

28. Тесленко М. Право як інструмент соціальної справедливості // Право України. 2004. № 7. С. 40-43.

29. Шайгородський Ю. Суспільна мораль як система цінностей // Правові засади захисту особистісних цінностей та суспільної моралі: зб-к нормативних актів України / Уклад.: Ю. Ж. Шайгородський, К. П. Меркотан. К. : Укр. центр політ. менеджменту, 2007. С. 3-20.

\section{References}

1. Hromadski orhanizatsii pidtrymuiut prosimeinu y antyhendernu pozytsiiu sekretaria RNBO // Tsenzor.Net. 29.12.2018. URL: https://m.censor.net.ua/ua/news/3104609/gromadski_organizatsiyi_pidtrymuyut_prosimeyinu_ yi_antygendernu_pozytsiyu_sekretarya_rnbo?fbclid=IwAR1yunGF756hs6d-gQrTEz214ZPyUN_CijhRHr7SYTaCrvtmv1-V7cK8y0

2. Zahalna teoriia derzhavy i prava : navch. posib. / [za red. V. V. Kopieichykova]. K. : Yurinkom Inter, $2000.320 \mathrm{s.}$

3. Zahalni pravyla etychnoi povedinky derzhavnykh sluzhbovtsiv ta posadovykh osib mistsevoho samovriaduvannia: Zatverdzheno Nakazom Natsionalnoho ahentstva Ukrainy z pytan derzhavnoi sluzhby vid 05.08.2016. № 158 // Ofitsiinyi veb-portal Verkhovnoi Rady Ukrainy. URL: http:zakon3.rada.gov.ua/laws/show/z1203-16/paran13\#n13.

4. Zakon Ukrainy «Pro derzhavnu sluzhbu v Ukraini» № 889-VIII vid 10.12.2015 r. // Ofitsiinyi veb-portal Verkhovnoi Rady Ukrainy «Zakonotvorchist». URL: http://zakon2.rada.gov.ua/laws/show/889-19.

5. Zakon Ukrainy «Pro zapobihannia koruptsii» vid 14 zhovtnia 2014 roku № 1700-VII // URL: Ofitsiinyi veb-portal Verkhovnoi Rady Ukrainy. URL: http:zakon3.rada.gov.ua/laws/show/1700-18/page.

6. Zakon Ukrainy «Pro zakhyst suspilnoi morali» vid 20 lystopada 2003 r. № 1296-IV // Ofitsiinyi veb-portal Verkhovnoi Rady Ukrainy «Zakonotvorchist». URL: http://zakon.rada.gov.ua/laws/show/1296-15 
7. Zakon Ukrainy «Pro osvitu» № 2145-VIII vid 05.09.2017 r. Ofitsiinyi veb-portal Verkhovnoi Rady Ukrainy «Zakonotvorchist». URL: https://zakon.rada.gov.ua/laws/show/2145-19

8. Kozlovets M. A. Fenomen natsionalnoi identychnosti: vyklyky hlobalizatsii : monohrafiia. Zhytomyr: Vyd-vo ZhDU im. I. Franka, 2009. S. 449.

9. Korzhanskyi M. Y. Pravo i zakon // Naukovyi visnyk Yurydychnoi akademii Ministerstva vnutrishnikh sprav : Zbirnyk naukovykh prats. 2003. № 3 (12). S. 52-52.

10. Kostenko O. M. Kultura i zakon - u protydii zlu: monohrafiia. K. : Atika, 2008. $352 \mathrm{s.}$

11. Kostytskyi $V$. V. Norma prava yak sotsialnyi fenomen: teoloho-sotsiolohichne pravorozuminnia // Sotsiolohiia prava: naukovo-praktychnyi zhurnal. 2015. № 3-4 (14-15). S. 3-10.

12. Kravets V. M. Pryrodne pravo yak ideia ta ideal pozytyvnoho prava // Filosofski ta metodolohichni problemy prava. Vyp. 1. K. : 2009. S. 35-41.

13. Kryterii // Nauka i zhyttia. Vyp. 8. 1956. S. 36.

14. Makarenko L. O. Koruptsiia yak vyznachalnyi faktor ruinuvannia pravovoi kultury v Ukraini // Almanakh prava. Pravova analityka: doktrynalni pidkhody ta haluzevi vymiry. Vyp. 9. K. : In-t derzhavy i prava im. V. M. Koretskoho NAN Ukrainy, 2018. S. 208-215.

15. Maksymov S. Pryrodne i pozytyvne pravo yak elementy pravovoi realnosti // Mizhnarodna politseiska entsyklopediia: u 10 t. Vidp. red. Yu. I. Rymarenko, Ch. Yu. Kondratiev ta in. K. : In Yure, 2003. S. 891-894.

16. Nakaz MON Ukrainy № 1183 vid 31 zhovtnia 2018 r. «Pro zatverdzhennia instruktyvno-metodychnykh materialiv dlia provedennia ekspertamy ekspertyz elektronnykh versii proektiv pidruchnykiv» // Ofitsiinyi sait Ministerstva osvity i nauky Ukrainy. URL: https://mon.gov.ua/ua/npa/pro-zatverdzhennya-instruktivno-metodichnih-materialivdlya-provedennya-ekspertami-ekspertiz-elektronnih-versij-proektiv-pidruchnikiv

17. Naukovtsi zaklykaiut Kabmin likviduvaty posadu upovnovazhenoho z pytan hendernoi polityky // «Vsi razom». Hromadianskyi rukh. 29.12.2018. URL: https:/vsirazom.ua/poziciya/naukovci-zaklikayut-kabmin-likviduvatiposadu-upovnovazhenogo-z-pitan-genderno\%D1\%97-politiki?fbclid=IwAR1JJ3QFzMy7fWHDsFMfNHFyjfYXbS sywy9WW5131YkrI_dNG_7vu-IHahQ

18. Oborotov Yu. N. Paradyhma tsennostno-normatyvnoho ponymanyia // Pravove zhyttia suchasnoi Ukrainy: Tezy dopovidei Vseukrainskoi naukovoi konferentsii / Vidp. red. prof. Yu. M. Oborotov. O. : Feniks, 2008. S. 5-6.

19. Onishchenko N. M. Pravovyi svitohliad: liudynotsentryskyi vymir // Transformatsiia pravovoi ideolohii u konteksti suchasnykh vyklykiv : monohrafiia / kol. avtoriv; za zah. red. N. M. Onishchenko. K. : TOV «Nilan-LTD», 2016. S. 63-105.

20. Plavych $S$. V. Teoretyko-metodolohichni zasady pravotvorchosti : dys. ...kand. yuryd. nauk : 12.00.01. K., 2009. $215 \mathrm{~s}$.

21. Rabinovych S. P. Pryrodno-pravovi pidkhody v yurydychnomu rehuliuvanni : monohrafiia. Lviv : Lviv. derzh. un-t vnutr. sprav, 2010. $576 \mathrm{~s}$.

22. Rishennia Konstytutsiinoho Sudu Ukrainy № 15-rp/2004 vid 02 lystopada 2004 r. po spravi № 1-33/2004 za konstytutsiinym podanniam Verkhovnoho Sudu Ukrainy shchodo vidpovidnosti Konstytutsii Ukrainy (konstytutsiinosti) polozhen statti 69 Kryminalnoho kodeksu Ukrainy (sprava pro pryznachennia sudom bilsh miakoho pokarannia) // Ofitsiinyi veb-portal Verkhovnoi Rady Ukrainy «Zakonotvorchist». URL: http://zakon3.rada. gov.ua/laws/show/v015p710-04.

23. Selivanov V. Netotozhnist prava i zakonu (metodolohichnyi aspekt) // Pravo Ukrainy. 2005. № 5. S. 7-11.

24. Syrenko V. Hosudarstvo: demokratycheskoe, pravovoe, sotsyalnoe (Ocherky. Dyskussyonnыe voprosы). K. : Yn-t hosudarstva y prava ym. V. M. Koretskoho NAN Ukraynd, 2013. $340 \mathrm{~s}$.

25. Slovnyk ukrainskoi movy: v 11 tomakh. T. 4. 1973. S. 349.

26. Sovetskyi эntsyklopedycheskyi slovar/hlav red. A. M. Prokhorov. Yzd-e 2-e. M. : Sov. эnts., 1983. $1600 \mathrm{~s}$.

27. Suniehin S. O. Pravo, moral i relihiia yak sotsialni rehuliatory: obiektyvnyi ta subiektyvnyi vymiry // Pravova derzhava. Vyp. 28. K. : In-t derzhavy i prava im. V. M. Koretskoho NAN Ukrainy, 2017. S. 145-163.

28. Teslenko M. Pravo yak instrument sotsialnoi spravedlyvosti // Pravo Ukrainy. 2004. № 7. S. 40-43.

29. Shaihorodskyi Yu. Suspilna moral yak systema tsinnostei // Pravovi zasady zakhystu osobystisnykh tsinnostei ta suspilnoi morali: zb-k normatyvnykh aktiv Ukrainy / Uklad.: Yu. Zh. Shaihorodskyi, K. P. Merkotan. K. : Ukr. tsentr polit. menedzhmentu, 2007. S. 3-20.

\section{Львова О. Л. Критерії моральності і природності у сучасному правотворенні}

У статті наголошується на актуальності вивчення питання праворозуміння, зокрема, у контексті розмежування категорій «право» і «закон», розуміння природного, морального та справедливого.

Історія доводить, що кризи у державно-правових процесах породжуються, передусім, кризами моралі, які беруть свій початок з людини чи групи людей, на яких лежить тягар відповідальності за свій народ. У зв’язку з цим, суб'єкт правотворчості своєю головною метою має таке подвійне завдання: 1) співвідносити свою особистість і внутрішні моральні якості з соціокультурним, моральним контекстом суспільного життя конкретного народу; 2) здійснювати спостереження та моніторинг права, що де-факто, природно або в силу традиції чи звичаїв існує 
у суспільних відносинах, і формалізувати його у вигляді конкретних правових норм з метою консолідації суспільства й захисту природних прав людини.

Підкреслюється законодавче визначення моралі як системи етичних норм, правил поведінки, що склалися у суспільстві на основі традиційних духовних і культурних цінностей, уявлень про добро, честь, гідність, громадський обов'язок, совість, справедливість. Щодо природності в юридичній літературі говориться, що універсальним критерієм для діагностування соціальних патологій є критерій протиприродності.

Як висновок констатується, що право є об'єктивною реальністю, що визначається загальносуспільним усвідомленням морального, справедливого, природного та істинного, що приносить благо як окремому індивіду, так і суспільству.

Ключові слова: верховенство права, закон, критерій, мораль, право, природність.

\section{Lvova O. L. Criteria of morality and naturalness in modern law-making}

The article emphasizes the relevance of the study of the problem of legal thinking, in particular, in the context of the delineation of the categories of «right» and «law», an understanding of the natural, moral and just.

History proves that crises in state-legal processes are generated, first of all, by the crises of morality that originate from a person or group of people who bear the burden of responsibility for their people. In this regard, the subject of law-making has its main objective as a dual task: 1) to correlate his personality and internal moral qualities with the sociocultural, moral context of the social life of a particular people; 2) monitor and monitor the law that de facto, naturally or by virtue of tradition or custom, exists in public relations, and formalize it in the form of specific legal norms for the purpose of consolidating society and protecting natural human rights.

At the same time, the markers of such conformity must become well-founded criteria, the main among which we consider the criteria of morality and naturalness, which are criteria of truth, which is not denied, since it does not depend on consciousness and human activity.

The legislative definition of morality as a system of ethical norms, rules of conduct in society based on traditional spiritual and cultural values, notions about goodness, honor, dignity, public duty, conscience, and justice are underlined. Regarding naturalness in the legal literature it is stated that the universal criterion for diagnosing social pathologies is the criterion of antinality: «all that is unnatural is a social pathology, that is evil».

Taking into account these criteria, the article analyzes the text of the draft of such documents of the Ministry of Education of Ukraine as the Strategy for the Promotion of Gender Equality and Non-Discrimination in he Field of Education «Education: Gender Dimension-2021» and the current Order of the Ministry of Education and Science of Ukraine «On Approval of Instructional and Methodological Materials for experts to conduct expert reviews of electronic versions of textbooks». In this case, neither the criterion of naturalness nor the criterion of morality has become a standard and a measure of law-making activity of the Ministry of Education and Science, and the criterion of non-discrimination and gender dimension, which contravenes the moral principles of society and violates the right of parents to the education of their own children according to their ideological beliefs and duty Parents influence the educational process.

As a conclusion, it is stated that the right is an objective reality, which is determined by the general social consciousness of moral, just, natural and true, which brings benefits both to an individual individual and to society in general.

Key words: rule of law, law, criterion, morality, law, naturalness.

DOI: 10.33.66.3/2524-017X-2019-10-167-175 